\title{
STUDIES ON VEGETATIVE DEVELOPMENT OF NAKED OAT (AVENA SATIVA GREX VAR. NUDAE MORDV) VARIETY "MINA" GROWN IN THE CONDITIONS OF ORGANIC FARMING IN SARKAR AGRO REGION
}

\author{
Violeta Vateva, Krasimir Trendafilov \\ Faculty of Techniques and Technologies, Trakia University, Bulgaria \\ Graf Ignatiev 38, 8600 Yambol, Bulgaria \\ e-mail: vili13@gmail.com, trendafdilov@outlook.com
}

\begin{abstract}
Naked oats is varietal variation of oats, whose potential is necessary to examine for the various agricultural regions in Bulgaria.

The objective of this experiment is to track down and to determine opportunities for growing Bulgarian naked oat variety "Mina", in ecological conditions of Sakar agricultural region.

The surveys were carried out during the period 2009-2011 in experimental base for the Sakar mountain of ISSAPP "N. Pushkarov" Sofia.

Under the too specific conditions of Sakar agricultural region and grown in organic farming the naked oats variety "Mina" shows good adaptability for growth and development. The vegetation period lasts 93-115 days. In the initial phases of its development the naked oats grew by $1.9-7.6 \mathrm{~cm}$, in the phases of the active growing season grew by $8.3-12.3 \mathrm{~cm}$. For the vegetation period the naked oats variety "Mina" grew by $64.9-74.2 \mathrm{~cm}$.
\end{abstract}

Keywords: naked oat, ecological conditions, vegetative development, dynamics of growth, Sakar agro region.

\section{INTRODUCTION}

The focus of modern farming is the cultivation of crops in the conditions of organic farming. According to statistics, every year the demand for organically produced agricultural products is growing on average by $10-15 \%$ [10].

The organic farming seriously underlies in the projects of the EU regulations for the application of the common agricultural policy for the period 2014-2020. Conclusions of the European plan for organic food and farming are that Bulgaria has favorable opportunities for the production of organic products. In this context, in many parts of the country farmers turned to organic production of agricultural products [11].

After the accession of Bulgaria in the EU, requirements were placed for the production of agricultural produce, including for the most part of the cereal cultivation to be on the principles of organic farming. So part of the Bulgarian grain production was reoriented and took the new path.

The oats as a cereal falling within this group occupies a rightful place. To 2010 in Bulgaria on the principles of organic farming is produced about 4400 tons oat annually [4], [8].

The review on the studies of the naked oat shown that it is a preferred varietal variation of oats for growing [1], [2], [5], [9]. In Bulgaria are carried out researches on the possibilities of his growing in various regions of the country [2], [3], [6]. Oats "Mina" was recognized in 2005 by the Executive Agency for Variety Testing, Field Inspection and Seed Control (Bulgaria).

The objective of the present study was to explore the possibility of growing the naked oat variety "Mina" in conditions of organic farming in Sakar agroregion. The vegetative development of oats is traced - phases of growth and development, duration of periods

IRTIIE Vol. 4, No. 1, 2016 ISSN 1314-8788 (print), ISSN 1314-8796 (online), doi: 10.15547/artte.2016.01.003 


\section{ARTTIE $Y$}

Ipplied Researrches in Technics, Technologies and Educiation

Journal of the Faculty of Technics and Technologies, Trakia University https://sites.google.com/a/trakia-uni.bg/artte/

between phases, duration of the growing season, dynamics of growth during the growing season (measured in every ten days), the height of the crop in the various phases of its development and growth for the growing season.

\section{MATERIAL AND METHODS}

The experiment was carried out at the research base of the ISSAPP "N. Pushkarov" Sofia for the Sakar Mountain (the area of the town of Topolovgrad, Reg. Haskovo). The surveys were carried out in the period 2009-2011 under natural field conditions of Sakar agroregion.

Sakar agroregion has very specific natural-climatic conditions. The climate is continental with expressed Mediterranean influence. The soil is leached cinnamon forest with an acidic reaction ( $\mathrm{pH} 4.5)$ and the content of humus is less than $2 \%$.

In the previous year, the area provided for the experiment was ploughing to a depth of 26-28 $\mathrm{cm}$. The predecessor of oats is peas grown for grain. In the last week of February the area is cultivating and disking. Sowing is carried out at the earliest opportunity at the beginning of March (2-3. III). The seeds of naked oat variety "Mina" are supplied by The Institute for Plant Genetic Resources "K. Malkov", town of Sadovo. The experience was factored in three repetitions with experimental area $20 \mathrm{~m} 2(2 \times 10 \mathrm{~m})$. Sowing of oats is made with sowing norm $18 \mathrm{~kg} / \mathrm{da}$. Mineral fertilization and plant protection with chemicals have not been carried out.

\section{RESULTS AND DISCUSSION}

The oats is a cereal grain, which has certain requirements to the weather conditions. It is a culture of cool and humid climate and often the climate indicators who are unfavorable to the growth and development may affect negatively on its development and productivity.

Sakar agro-ecological region is ranking as one of the warmest and with pronounced periods of drought in Bulgaria [7]. The norm of rainfall in the region is lower than the average rate for the country, and the average annual air temperature is one of the highest in Bulgaria.

In terms of climate the period in which the experiment was carried out is characterized by significant deviations from the established norms for the region. The quantities of rainfall during the first and second year are higher with $65.5-120.8 \mathrm{~mm}$, and in the third year has $34.1 \mathrm{~mm}$ rainfall less than the norm for the area (fig. 1).

The average annual temperature of the air during the three years of the research was higher than the norm for the region with $0.5-2.3^{\circ} \mathrm{C}$. The first year of the research (2009) is the warmest and with significantly higher annual average compared to the norm for the region.

The vegetative development of oats from germination to the ripening is conditioned by the manifestation of climate indicators in the period from February to July. Apparent from Figure 2 is that in both climatic indexes (monthly amount of precipitation and average monthly air temperature) over the three years of the study there is significant departures from established norms for the region.

February and March in the first and second years of research are well provided with moisture. This creates problems for soil cultivation and sowing. April and May have less rainfall amounts in 2009 and 2010 years and they are well provided with moisture in the third year. June and July are again with high moisture during the first two years and insufficient rainfall in the third year.

Data from the monthly average temperatures show that during the first year only in April it she comes close to the norm for the region and in all other months is significantly higher. In the second year with normal temperatures are the months of March and April. The third year is the closest to normal values of average monthly temperatures for the period III - VII, as an exception makes only the month of July.

IRITIE Vol. 4, No. 1, 2016 ISSN 1314-8788 (print), ISSN 1314-8796 (online), doi: 10.15547/artte.2016.01.003 


\section{ARITIE}

Ipplied Researroches in Technics, Technologies and Eduration

Journal of the Faculty of Technics and Technologies, Trakia University https://sites.google.com/a/trakia-uni.bg/artte/

The alternation of periods of over-moisture and dry periods with high temperatures affect the vegetative development of oats. Due to the high humidity and frequent rains during the first year of the research, sowing was carried out later, and in subsequent years it was carried out at the beginning of March (Table. 1). Germination of oat in a normal weather conditions is 13 days after sowing. In critical weather situations, as is the case in the third year (low moisture in February and March 2011) is 16 days after sowing.

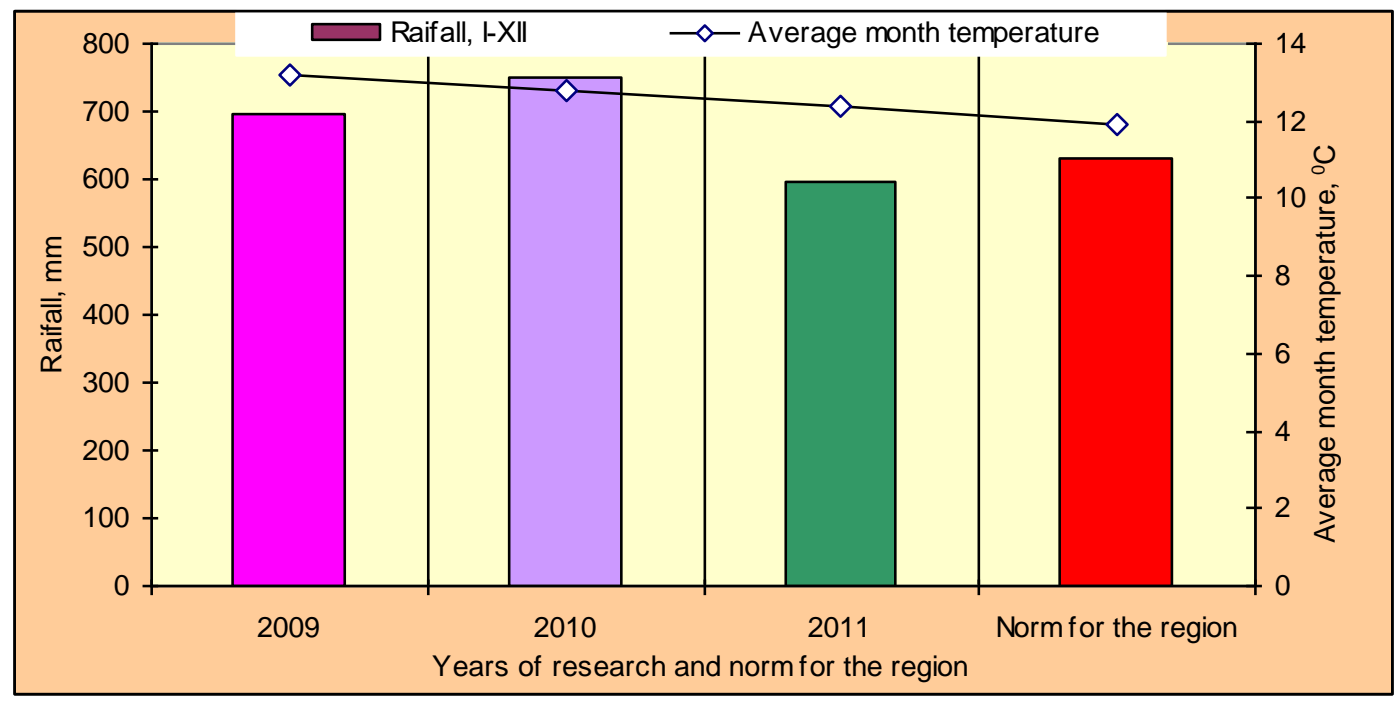

Figure 1.

The annual amount of precipitation and the average annual air temperature in the years of the research and norm for the region
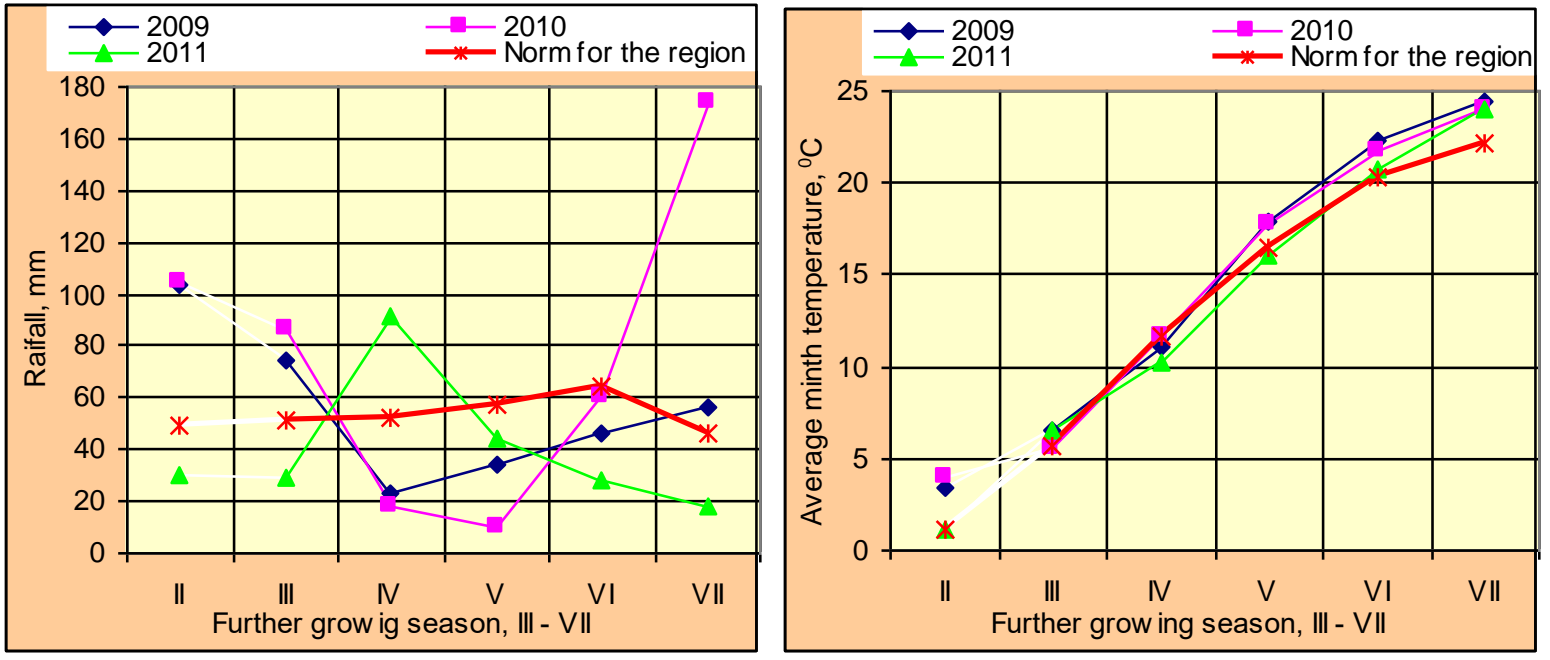

Figure 2.

Monthly amount of rainfall $(\mathrm{mm})$ and monthly average air temperature $\left({ }^{0} \mathrm{C}\right)$ during II - VII month by the years of research and norm for the region 


\section{ARITIE}

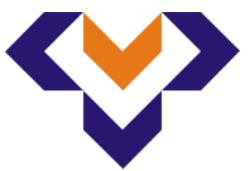

Ipplied Resseirl ches in Technics, Technologies and Bductation

Journal of the Faculty of Technics and Technologies, Trakia University https://sites.google.com/a/trakia-uni.bg/artte/

Table 1. Dates of sowing, emergence application, harvesting, length of growing season and growth for the growing season $(\mathrm{cm})$

\begin{tabular}{|c|c|c|c|c|c|c|}
\hline Year & Sowing & $\begin{array}{c}\text { Date of } \\
\text { emergence } \\
\text { application }\end{array}$ & $\begin{array}{c}\text { Emergence } \\
\text { application } \\
\text { of... }\end{array}$ & $\begin{array}{c}\text { Number of } \\
\text { Date of } \\
\text { harvest }\end{array}$ & $\begin{array}{c}\text { days in the } \\
\text { growing } \\
\text { season }\end{array}$ & $\begin{array}{c}\text { Growth for the } \\
\text { growing } \\
\text { season, cm }\end{array}$ \\
\hline 2009 & $22 . \mathrm{III}$ & $4 . \mathrm{IV}$ & 13 day & $3 . \mathrm{VII}$ & 93 & 69.9 \\
\hline 2010 & $3 . \mathrm{III}$ & $16 . \mathrm{III}$ & 13 day & $5 . \mathrm{VII}$ & 108 & 74.2 \\
\hline 2011 & $1 . \mathrm{III}$ & $17 . \mathrm{III}$ & 16 day & $10 . \mathrm{VII}$ & 115 & 64.9 \\
\hline
\end{tabular}

Under the terms of the Sakar agroregion the duration of the growing season of the spring oat variety "Mina" ranged from 93 to 115 days. Conventionally this duration is also subordinated to the manifestation of the climate indicators.

Phenological observations taking into account the phases of development on the naked oats variety "Mina" show that the longest are periods between phases tillering / first node and first node / inflorescence emergence last spikelet visible (18-19 days) (Table 2).

The period between phases Inflorescence emergence last spikelet visible / milk ripening 1517 days. The shortest is the third period third leaf / tillering -6 days. From Table 2 can be seen that in the first and second years there is almost no difference in the duration of the periods between phases. A certain difference is observed in the third year of research, which is actually with the longest growing season.

Table 2. Duration of the periods between phases in the years of research

\begin{tabular}{|c|c|c|c|c|c|c|c|c|}
\hline \multirow[b]{2}{*}{$\begin{array}{l}\stackrel{\bar{ঠ}}{\circlearrowright} \\
\stackrel{\nu}{ }\end{array}$} & \multicolumn{8}{|c|}{ Period between phases, days } \\
\hline & 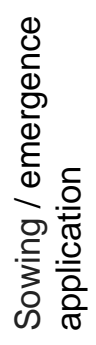 & 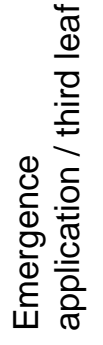 & 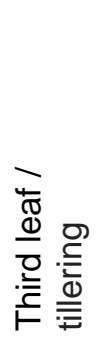 & 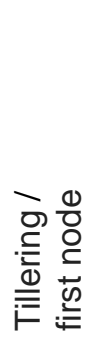 & 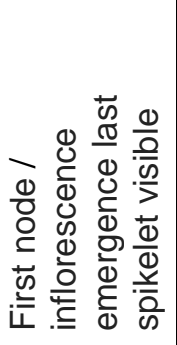 & 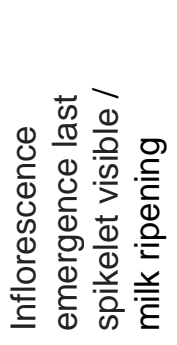 & 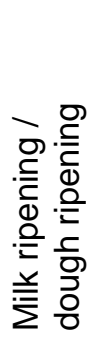 & 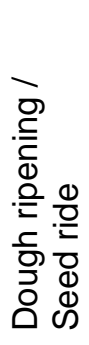 \\
\hline 2009 & 13 & 10 & 6 & 18 & 18 & 15 & 10 & 13 \\
\hline 2010 & 13 & 12 & 6 & 19 & 18 & 17 & 10 & 13 \\
\hline 2011 & 16 & 13 & 8 & 19 & 19 & 17 & 12 & 14 \\
\hline
\end{tabular}

In botanical description the naked oats variety "Mina", visually is overlapping with other cereals - fibrous root system, hollow stem composed of nodes and internodes reaching in the years of the research 56,4 - 66,7 cm, inflorescence panicle, grain with sharp and elongated form (Figure 3).

In this variety is noticed the difference from the other varieties of oats. The stem is more gentle and deep green colored. Panicle is upright and piled up to the central axis, and almost no dissipation and lodging. The length of the Panicle ranges from 18,5 to $21,7 \mathrm{~cm}$, and the number of grains per panicle is in the range of $28-33$ the number. These indicators are directly related to the yield of grain. The husk does not cover well the grain and part of it remains uncovered. Ripening of the grains of panicle is quite uneven process, and is a mistake to wait for full ripening of oats. 


\section{IRTITIE}

Ipplied Reserertches in Technics, Technologies and Bduration Journal of the Faculty of Technics and Technologies, Trakia University https://sites.google.com/a/trakia-uni.bg/artte/
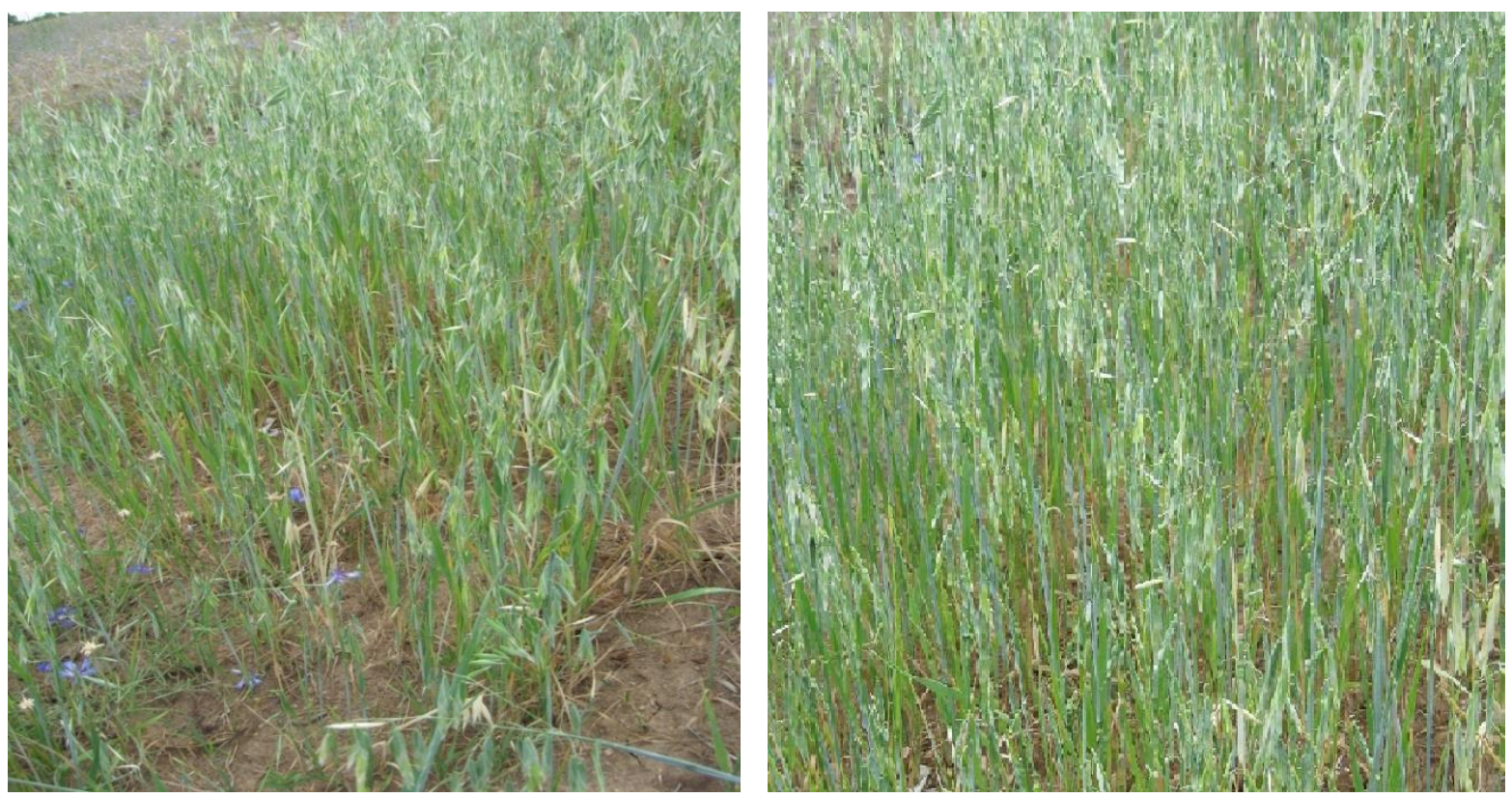

Figure 3. Naked oat variety "Mina" grown under conditions of Sakar agro-ecological region phase of "Milk ripening"

The dynamics of growth of oats in the period of research under the conditions of organic farming is a direct reflection of the manifestation of climate indicators during this period. Because of the three years of research the climatic conditions have a significant deviations from the norm for the region, in the vegetative development of the investigational variety have outliers in terms of germination, the duration of the periods between phases, the height in "harvesting" phase, etc.

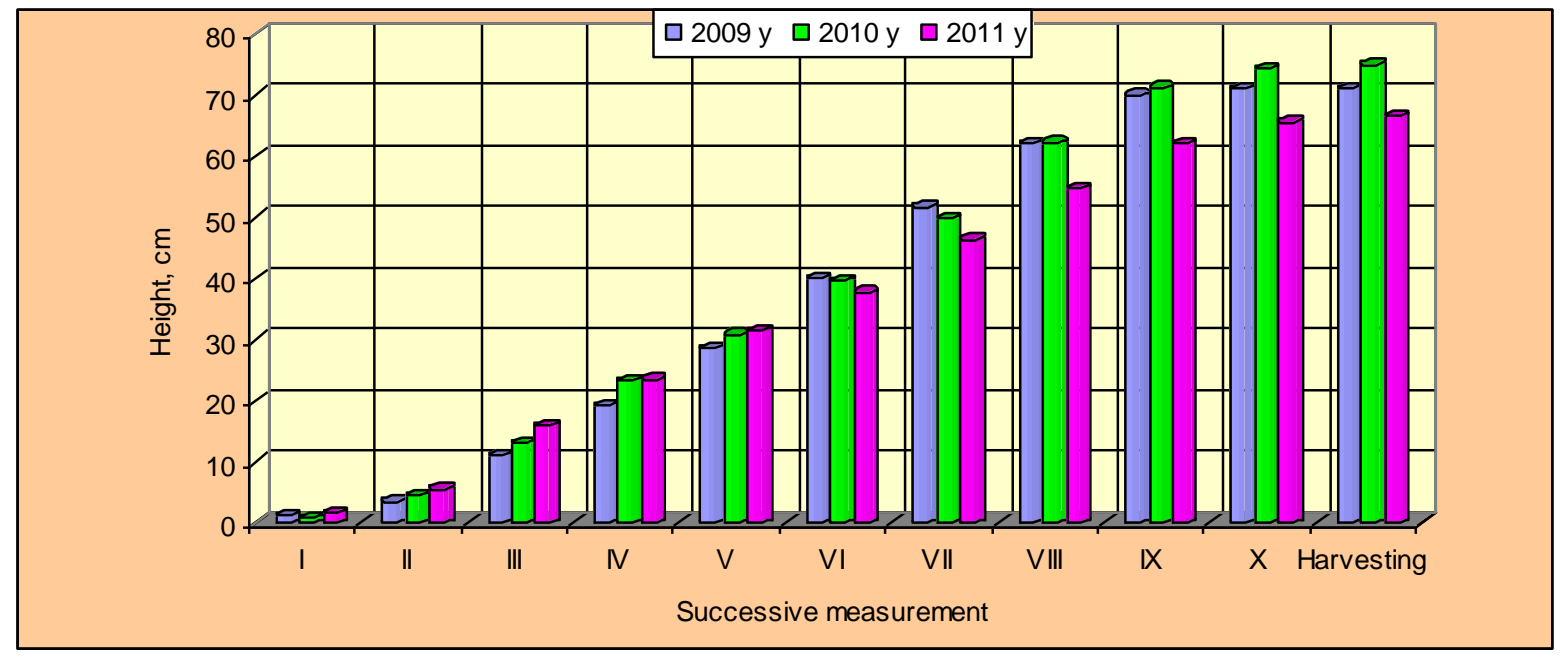

Figure 4. Dynamics of growth of naked oat variety "Mina" during the growing season from month III to harvesting in month VII by years of research, $\mathrm{cm}$ 


\section{IRTTIE

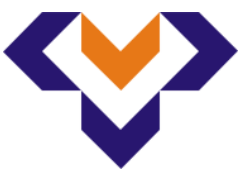

Ipplied Researthes in Technics, Technologies and Bduration

Journal of the Faculty of Technics and Technologies, Trakia University https://sites.google.com/a/trakia-uni.bg/artte/

At the start of vegetative growth, after the moment of sprouting, the plants are with a height of $0.8-1.6 \mathrm{~cm}$ (fig. 4). In the first week after the start of the growing season oats grow slowly. About one month after germination it reaches a height of $9-11 \mathrm{~cm}$, then began a more dynamic growth and in phase third leaf / tillering has a height of 20,7 - 28,6 cm. In phase Inflorescence emergence last spikelet visible / milk ripening has a height of 44.6 to $50 \mathrm{~cm}$. Technological maturity occurs in early July and at this point naked oats has a height of 66.5 $75 \mathrm{~cm}$.

As well as Figure 4 shows, the dynamics of growth is at a slower pace at the beginning of the growing season, as it ranges from 1,9 to 7,6 cm. More intense growth rate is observed during the active growing season, which is in the second ten days of May and the first ten days of June. The increase in this period of 10 days is $8,3-12,3 \mathrm{~cm}$.

\section{CONCLUSIONS}

The researches on opportunities for growing the naked oat variety "Mina", in the condition of organic farming in Sakar agro region can be summarized in the following:

1. Due to the significant deviation of the climatic parameters from the established norms for Sakar agro-ecological region in the period of the research, is difficult to meet the sowing deadlines. For this reason, in one of the years the sowing was delayed and was made on 22.III.

2. The deviation of the climatic parameters from established norms effects on the dynamics of growth and vegetative development of oats.

3 . In those weather conditions and in an environment of organic farming, naked oat variety "Mina" grow for growing season with $64,9-74,2 \mathrm{~cm}$.

4. The length of the growing season is between 93-115 days, in phase "harvesting" the oats has a height of 66.5 to $75 \mathrm{~cm}$.

5. At the beginning of the growing season naked oats is growing more slowly, with 1,9 $-7,6$ $\mathrm{cm}$, and during the period of active vegetation the growth rate is accelerating.

6. In phase ready for harvesting oats is in the first ten days of July.

7. Although observed departures from established norms and sowing deadline, can be recommended cultivation of naked oat variety "Mina" under the conditions of organic farming in Sakar agro region.

\section{REFERENCES}

[1] Antonova, N. (2005). Potential and perspectives of wintering naked oats. Plant Science, 40, 200-204. (Bg)

[2] Antonova, N., Stancheva J., Dobrev D., Karadjova J., (1995). Spring naked oats variety "Mina". Jubilee scientific Conference "90 years IASS "Obraztsov chiflik" - Ruse, Scientific works I, 51-55. (Bg)

[3] Slavova, T., Dyulgerova B.. (2015). Selection value of naked oat samples (Avena nuda, L.).www.iz-karnobat.com/wp-content/uploads/2015/03/16.Селекционна-ценност-набразци.pdf. (Bg)

[4] Spasova D., Spasov D., Atanasova B., Ilievski M., Kukutanov R., Georgieva T.. (2013). Impact of the system of cultivation on the vegetative growth and reproductive development of oats. Bulgarian Journal of Agricultural Science, Agricultural Academy, 19 (No 5), 1047-1055.

[5] Sterba, Z., Moudry J., (2001). Yield formation and quality of naked oats (Avena nuda L.). 37th Croatian symposium on agriculture, 262.

[6] Tanchev, E., Antonova N.. (2010). Research productivity of naked oat varieties under the terms of the Strandzha region. Field crops studies, Vol. 6-2, 321-324.

IRTIIE Vol. 4, No. 1, 2016 ISSN 1314-8788 (print), ISSN 1314-8796 (online), doi: 10.15547/artte.2016.01.003 


\section{IRTITE}

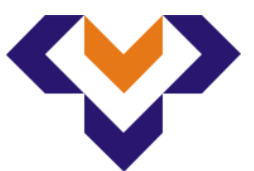

Ipplied Reseirl'ches in Technics, Technologies and Bducation

Journal of the Faculty of Technics and Technologies, Trakia University https://sites.google.com/a/trakia-uni.bg/artte/

[7] Vateva, V. (2005). Soil conservation and economic effects of fertilization of natural and artificial grass cover in the region of Sakar, IP "N. Pushkarov" Sofia Dissertation for awarding the scientific degree "Doctor". (Bg)

[8] Zorovski, P., (2012). Study on the biological and economic qualities of oat varieties in relation to using them as healthy food for people. Dissertation, AU Plovdiv. (Bg)

[9] Zorovski, P., Georgiev T.. (2010). Yield of spring filmy and naked oats varieties under the action of growth regulators Humustim and immunocitofit in the central part of southern Bulgaria. II international scientific and practical Conference, Irkutsk, 152-160. $(\mathrm{Ru})$

[10] www.organic-farming.europa.eu/.

[11] www.mzh.goverment.bg. 